Hydrology and Earth System Sciences, 8(1), 8-22 (2004) (C) EGU

\title{
Groundwater redox conditions and conductivity in a contaminant plume from geoelectrical investigations
}

\author{
V. Naudet ${ }^{1}$, A. Revil ${ }^{1}$, E. Rizzo ${ }^{1}$, J.-Y. Bottero ${ }^{2}$ and P. Bégassat ${ }^{3}$ \\ ${ }^{1}$ CNRS-CEREGE, Dept. of Hydrogeophysics and Porous Media, Aix-en-Provence, France \\ ${ }^{2}$ CNRS-CEREGE, Dept. of Interfacial Chemistry, Aix-en-Provence, France \\ ${ }^{3}$ ADEME, 2, Square La Fayette BP 406, Angers, France \\ E-mail for corresponding author: revil@cerege.fr
}

\begin{abstract}
Accurate mapping of the electrical conductivity and redox potential of groundwater is important in delineating the shape of a contaminant plume. A map of redox potential in an aquifer is indicative of biodegradation of organic matter and of concentrations of redox-active components; a map of electrical conductivity provides information on the mineralisation of the groundwater. Both maps can be used to optimise the position of pumping wells for remediation. The self-potential method (SP) and electrical resistivity tomography (ERT) have been applied to the contaminant plume associated with the Entressen landfill in south-east France. The self-potential depends on groundwater flow (electrokinetic contribution) and redox conditions ('electro-redox' contribution). Using the variation of the piezometric head in the aquifer, the electrokinetic contribution is removed from the SP signals. A good linear correlation $\left(\mathrm{R}^{2}=0.85\right)$ is obtained between the residual SP data and the redox potential values measured in monitoring wells. This relationship is used to draw a redox potential map of the overall contaminated site. The electrical conductivity of the subsoil is obtained from 3D-ERT analysis. There is good linear correlation $\left(\mathrm{R}^{2}=0.91\right)$ between the electrical conductivity of the aquifer determined from the 3D-ERT image and the conductivity of the groundwater measured in boreholes. This indicates that the formation factor is nearly homogeneous in the shallow aquifer at the scale of the ERT. From this correlation, a map of the pore water conductivity of the aquifer is obtained.
\end{abstract}

Keywords: self-potential, redox potential, electrical resistivity tomography, fluid conductivity, contaminant plume

\section{Introduction}

In industrialised countries, over $1 \mathrm{~kg}$ of municipal and domestic waste is produced per day, per inhabitant; most of it is deposited in municipal landfills. In the last decade, the increasing public concern with groundwater management problems due to waste disposal has generated significant hydrogeological and geochemical research activity. This research concerns, for example, the mapping of the redox potential and the electrical conductivity of the groundwater, which are two key-parameters for the characterisation of contaminant plumes and for site remediation technologies (Christensen et al., 2000, 2001; Kemna et al., 2002). The redox potential is sensitive to organic matter associated with landfill leachate and its biodegradation by bacterial colonies plus the presence of specific electro-redox components (Atlas, 1981; Christensen et al., 2000, 2001; Vayenas et al., 2002). The conductivity of the groundwater indicates its ionic strength and its degree of ionic mineralisation, e.g. elevated concentrations of heavy metals. Mapping these two parameters in the field by classical geochemical methods is often difficult because borehole measurements are expensive and invasive and provide only scarce information. In addition, these measurements are time-consuming and can perturb local equilibria. For groundwater sampling in observations wells, the samples are taken after 30 minutes of purging when the geochemical parameters are constant. Also, the introduction of a sampling cell into a borehole generates disturbances due to the introduction of oxygen, which perturbs in situ redox potential measurements. Establishment of steady state conditions in a borehole can then take from a few hours to a few weeks (Christensen et al., 2000; Schulte-Ebbert and Hofmann, 2000). Consequently, few properly constrained maps of redox potential have been obtained to date over contaminated sites. 
Driven by the need for a cost-effective and a more continuous characterisation of contaminated groundwater, growing interest has emerged very recently in the use of non-intrusive geophysical methods (Aristodemou and Thomas-Betts, 2000; Yaramanci, 2000; Buselli and Lu, 2001; Kemna et al., 2002; Nimmer and Osiensky, 2002). In the present study, piezometric level data, geochemical measurements and geo-electrical methods (self-potential and electrical resistivity) have been combined in mapping the redox potential and the electrical conductivity in the contaminant plume associated with the migration of leachate from the municipal landfill of Entressen, in south-east France (Fig. 1).

The self-potential (SP) method involves the passive measurement of the electrical potential distribution at the ground surface of the Earth with non-polarisable electrodes; SP anomalies are associated with charge polarisation mechanisms occurring at depth and the method is sensitive to both fluid flow and redox conditions in the contaminant plume. Electrical resistivity tomography (ERT) is the measurement of the electrical field associated with the injection of current at the ground surface or in boreholes

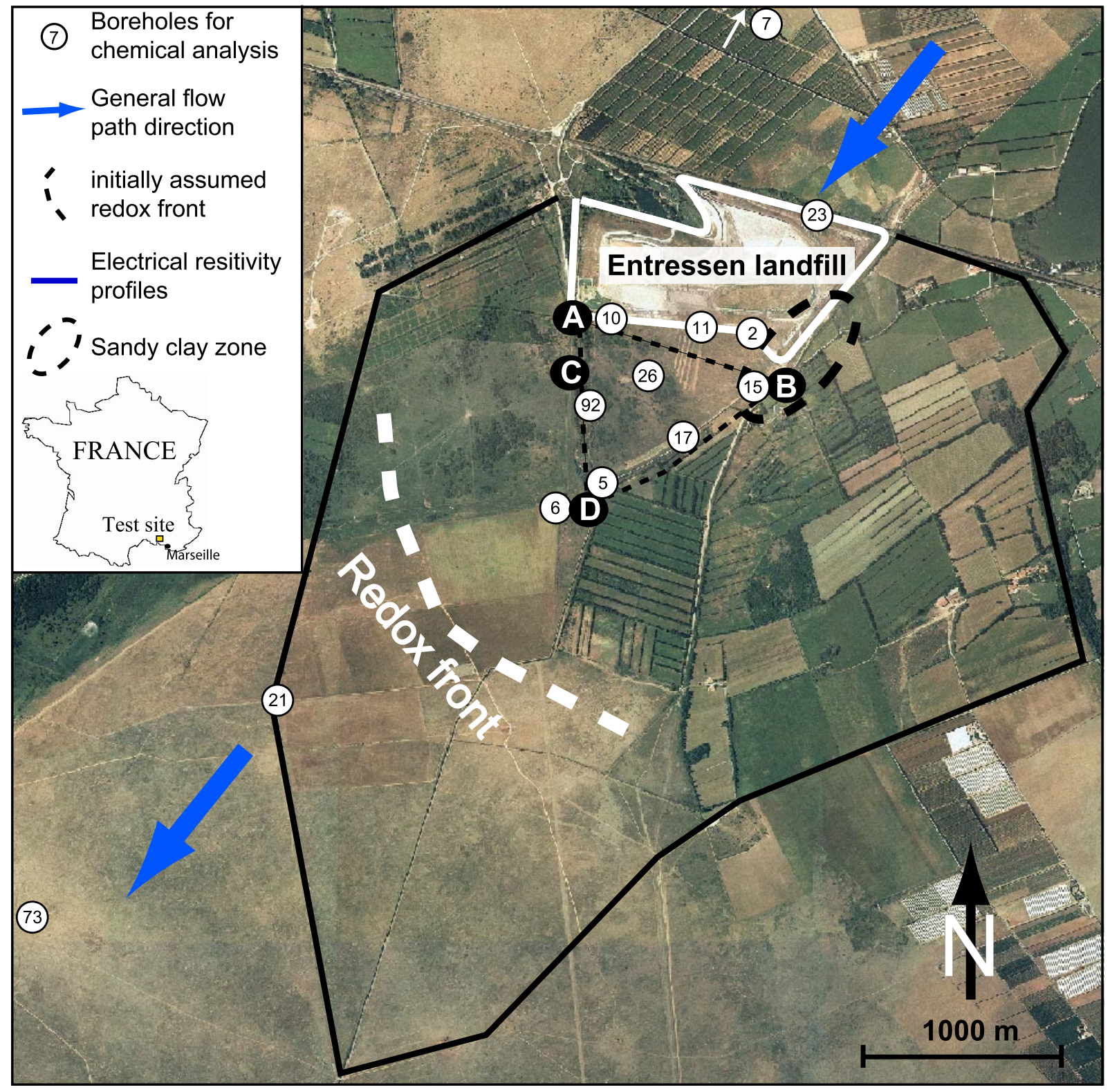

Fig. 1. Location of the Entressen landfill in the South-East of France near the city of Marseille. The dotted triangle ABD represents the area of the electrical resistivity measurements and black lines delineate the extension of the self-potential measurements. The position of the redox front, deduced from chemical analyses in the boreholes (numbered open-circles), is also represented. 
(e.g. Binley et al., 2002); this method images the subsurface in terms of electrical resistivity distribution. To map the electrical conductivity of the groundwater in the contaminant plume, 3D geo-electrical information has been combined with geochemical data. The SP method is usually used to characterise subsurface fluid flow phenomena (Fournier, 1989; Doussan et al., 2002; Revil et al., 2002; Titov et al., 2002). However, because there are very few quantitative interpretations of self-potential anomalies in the context of contaminated sites (Minsley et al., 2003), this paper may be the first quantitative method developed to interpret selfpotential data over a contaminant plume associated with landfill leachate.

\section{Field Survey}

\section{THE ENTRESSEN LANDFILL}

The Entressen landfill in south-east France is near Marseille, in the 'La Crau' alluvial plain (Fig. 1), formed by old deposits of the River Durance, which, during the Pleiostocene, flowed from there directly into the Mediterranean. The Entressen landfill has been active since 1912. Currently, about 600000 tons per year of new municipal and domestic waste are stored directly on the ground without a bottom liner. The site covers about $0.5 \mathrm{~km}^{2}$ and its maximum height is $30 \mathrm{~m}$. Borehole data available over the area indicate that the portion impacted by the leachate comprises shallow quaternary alluviums, which contain calcareous, metamorphic and endogenous stones. The thickness of this sequence is variable but is always less than $12 \mathrm{~m}$. (Fig. 2). The substratum is composed of impermeable marls of Pliocene age (thickness $>20 \mathrm{~m}$ ). The interface between the alluvium sequence and the marls exhibits paleochannel structures. The piezometric data indicate that an unconfined aquifer exists between 2 and $12 \mathrm{~m}$ below ground level. The average piezometric gradient of this shallow aquifer is $3 \%$ and the water level change over the year is around one metre. This small yearly variation, surprising at first in this region, is due to agricultural irrigation during the dry season. In general, groundwater flows from the north-east to the south-west. However, there are some local flow path heterogeneities. For example, just in front of the landfill, the groundwater flow direction turns westward because of some paleochannels as mentioned above. The presence of a clay lens in the eastern part of the landfill also affects the flow

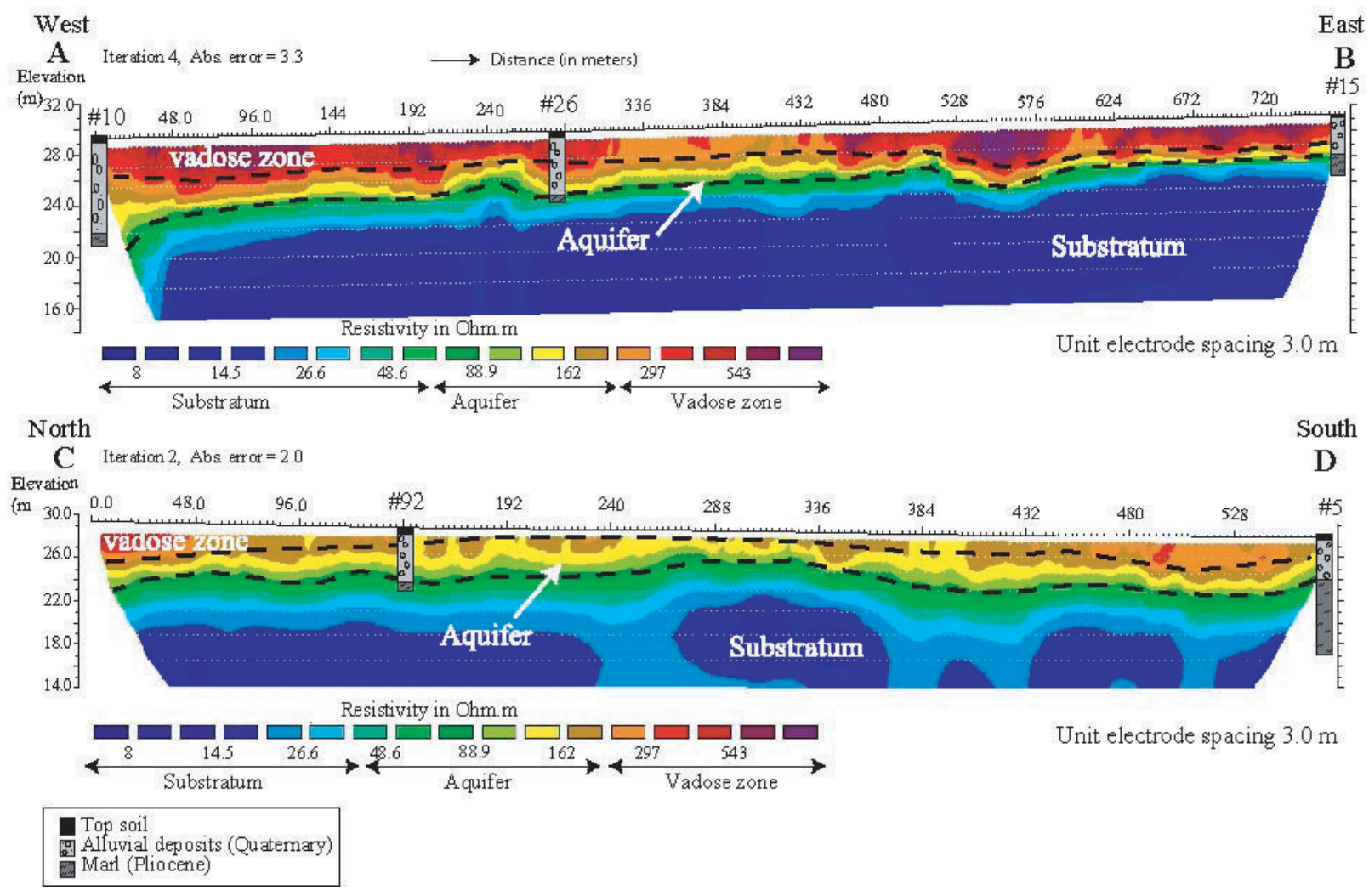

Fig. 2. 2D-electrical resistivity tomography (ERT) (Wenner configuration, electrode spacing $3 \mathrm{~m}$, absolute error given in \%). The profiles were inverted using the robust inversion scheme proposed in RES2DINV including topography. Geological borehole data constrain the geological interpretation. 
path there (Figs. 1 and 2).

Twelve wells currently monitor the quality of groundwater downstream (Fig. 1) plus a reference well (\#7) upstream which acts as the geochemical reference to the pristine aquifer. Table 1 presents the geochemical analyses performed by the municipality of Marseille and by Vilomet et al. (2001). The plume is delineated and characterised by high values of the electrical conductivity of the water and chloride concentrations. Wells 7, 21, 23 and 73 are located in an oxidised zone because of positive redox potential values, low electrical conductivity values of the groundwater and low concentrations of $\mathrm{Fe}(\mathrm{II})$ and $\mathrm{Mn}(\mathrm{II})$. The location of the redox front in Fig. 1 has been determined using these redox potential and geochemical data. A change from negative redox potential (reducing zone) to positive redox potential (oxidising zone) indicates the presence of a redox front, which lies between wells 5 and 21 . Because of the lack of boreholes for geochemical analyses in this zone, this location is not very precise so the self-potential method has been used to improve it. Vilomet et al. (2001) have also applied lead and strontium isotopes to characterise the different sources of contaminants and to delineate the maximum extension of the contaminant plume. They showed contamination up to $4.6 \mathrm{~km}$ away from the landfill (down to well \#73, Fig. 1). Part of the contamination between wells \#6 and \#21 is associated with agricultural fertilisers. The geochemical analyses show that the electron acceptors (oxygen, nitrate, Mn(IV) and Fe(III)-phases and sulphate) are subsequently reduced in the first kilometres downstream of the landfill (before well \#6). The high concentration of iron $\mathrm{Fe}^{2+}\left(\approx 21 \mathrm{mg} \mathrm{l}^{-1}\right.$ in well \#15) and its reduced concentration in wells \#6 $\left(7 \mu \mathrm{g} \mathrm{l}^{-1}\right)$ and \#21 $\left(<5 \mu \mathrm{g} \mathrm{l}^{-1}\right)$ indicate the presence of a redox front between wells \#6 and \#21 (Fig. 1 and Table 1). The redox front is established by the depletion of oxidised manganese and iron minerals in the solid phase, which explains the increase in the concentration of the reductively released ions in the aqueous phase (Table 1). However, because of a lack of monitoring wells for such a large contaminant plume, the hydrogeology and geochemistry of the site are not well determined. There is a large uncertainty regarding the precise location of the redox front between wells \#6 and \#21 (Fig. 1).

\section{SELF-POTENTIAL INVESTIGATIONS}

The self-potential method consists in passive measurements, at the ground surface or in boreholes, of natural electrical potential disturbances called self-potential anomalies, which are associated with some polarisation mechanisms occurring at depth. In the case of contaminated groundwater, the origin of SP signals comprises two main components: (1) an electrokinetic component associated with groundwater flow (Fournier, 1989; Birch 1998; Titov et al, 2002) and (2) an electrochemical component associated with oxidoreduction reactions (Nyquist and Corry 2002; Naudet et al., 2003). Noise sources are associated mainly with telluric currents and cultural noise.

The equipment required to map the self-potential is a MX20 Metrix-multimeter $\left(\sim 10^{8} \Omega\right.$ internal impedance $)$, one reel of wire (500 m long), and two non-polarising $\mathrm{Pb} / \mathrm{PbCl}_{2}$

Table 1. Chemistry of the monitoring boreholes. All the data came from the municipality of Marseille, which manages the landfill. $\mathrm{Mn}$ (II) and $\mathrm{Fe}$ (II) were measured by Vilomet et al., 2001. All the data are mean values over the year 2002, except for redox potential measured in 11/2001 and for Vilomet's data performed in 01/2000. DCO is the Direct Chemical Oxidation representative of the organic and chemical pollution.

\begin{tabular}{|c|c|c|c|c|c|c|c|c|c|}
\hline Wells & $E h(m V)$ & $\sigma_{f}\left(\mu S \mathrm{~cm}^{-1}\right)$ & $\mathrm{NH}_{4}^{+}\left(m g l^{-1}\right.$ & l) $\mathrm{NO}_{3}^{-}\left(m g l^{-1}\right)$ & $M n^{2+}\left(\mu g l^{-1}\right)$ & $\mathrm{Fe}^{2+}\left(\mu g l^{-1}\right)$ & $\mathrm{SO}_{4}^{2-}\left(m g l^{-1}\right)$ & $C l^{-}\left(m g l^{-1}\right)$ & $D C O\left(m g l^{-1}\right)$ \\
\hline$\# 2$ & -126 & 7984 & 960 & $<0.4$ & 336 & 20770 & 280 & 765 & 1015 \\
\hline$\# 5$ & -246 & 1162 & 1.3 & 0.4 & - & - & 160 & 110 & 55 \\
\hline$\# 6$ & - & - & - & 12.2 & 761 & 7 & 200 & 110 & - \\
\hline$\# 7$ & 138 & 673 & 0.1 & 16.6 & $<2$ & $<5$ & 100 & 24 & 32 \\
\hline$\# 10$ & -233 & 1280 & 46 & $<0.4$ & 497 & 90 & 120 & 105 & 67 \\
\hline$\# 11$ & -244 & 3388 & 185 & $<0.4$ & 120 & 864 & 180 & 425 & 264 \\
\hline$\# 15$ & -237 & 5735 & 250 & 1.6 & 308 & 21390 & 140 & 920 & 1500 \\
\hline$\# 17$ & -52 & 760 & 3 & 1 & - & - & 140 & 61 & 30 \\
\hline$\# 21$ & 114 & 1127 & 0.3 & 23 & $<2$ & $<5$ & 120 & 48 & 33 \\
\hline$\# 23$ & 68 & 765 & 0.2 & 12 & - & - & 110 & 25 & 30 \\
\hline$\# 26$ & -70 & 2176 & 55 & $<0.4$ & - & - & 270 & 235 & 142 \\
\hline$\# 73$ & 121 & 824 & 0.1 & 16.5 & $<2$ & $<5$ & 130 & 51 & 30 \\
\hline \#92 & -63 & 2253 & 63 & $<0.4$ & - & - & 160 & 100 & 130 \\
\hline
\end{tabular}


'Petiau' electrodes chosen for their stability (Petiau, 2000). The electrodes comprise a rod of lead immersed in kaolinite saturated by a $\mathrm{KCl} / \mathrm{PbCl}_{2}$ solution. One electrode is used as a fixed base station while the roving electrode is moved to each measurement station to scan the electrical potential at the ground surface. To ensure uniform ground contact between the electrodes, small holes $(\sim 10 \mathrm{~cm})$ were dug at each station, including the base station, and filled with $\sim 50 \mathrm{~g}$ of salty bentonite mud. As the soil was dry and rocky, the addition of bentonite mud improved the electrical contact with the ground and averaged the signal over a larger surface area of contact. In addition, to reduce the influence of local heterogeneities, the SP signal was measured in five different holes inside a $1 \mathrm{~m}^{2}$-circle at each measurement station. The selected SP value was, therefore, an average of these five measurements. These measurements had a standard deviation of $15-20 \mathrm{mV}$ which gave an estimate of the precision.

The gradient method, also called the 'leapfrog' technique, was combined with the fixed base station configuration to reduce cumulative errors and electro-telluric noise caused by variations in the earth's magnetic field and cultural sources (Corwin, 1990). To obtain a consistent map, survey lines were interconnected at numerous tie-in points to form loops. Based on Kirchoff's law, outside a source volume, the sum of the potential drops along a closed loop should tend to zero. If not, the tie-in loop closure errors are redistributed over the base stations of the loop, effectively closing the SP loop. In the present case, this corresponded approximately to a residual error of $5 \mathrm{mV}$ per base station. Then, all the SP data are referenced to a unique base station upstream of the landfill. From a SP study carried out from September 2001 to March 2002, with a $10 \mathrm{~m}$ sampling spacing near the landfill and a $20 \mathrm{~m}$ sample spacing in the southern part of the site (Naudet et al., 2003), a contour plot with triangular interpolation provided the self-potential map shown in Fig. 3. The interpolations were performed using the linear gridding option of Matlab $^{\circledR}$ software with a grid spacing of $10 \mathrm{~m}$.

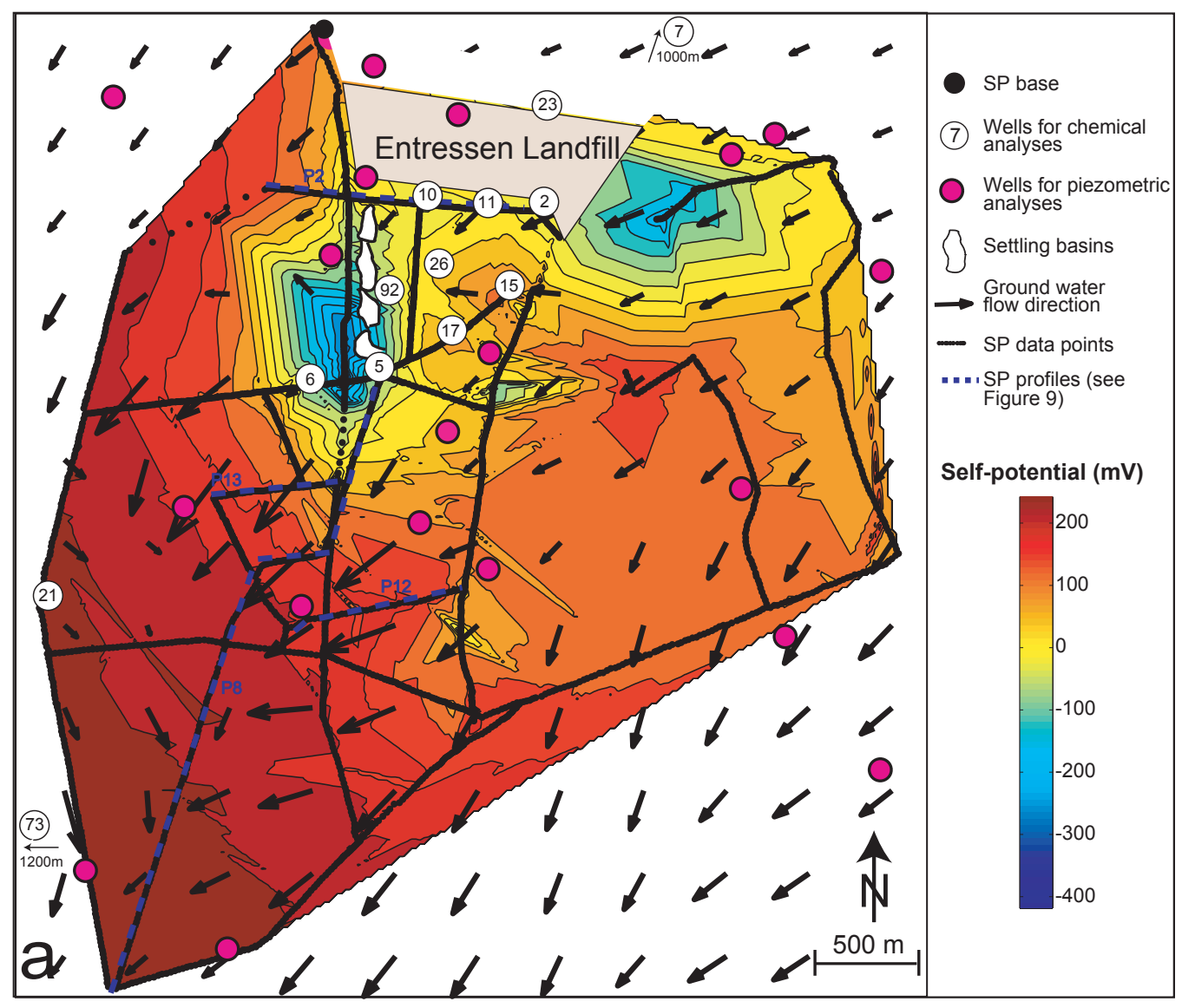

Fig. 3. Self-potential map (in $\mathrm{mV}$ ) obtained by linear interpolation using Matlab, with a $20 \mathrm{~m}$ grid. Black dots correspond to the 2800 SPmeasurements made in the field. The electrode spacing is $10 \mathrm{~m}$ in the first two $\mathrm{km}$ from the landfill and $20 \mathrm{~m}$ elsewhere. The arrows correspond to the piezometric gradient determined from a triangular interpolation of around forty piezometric head measurements in all the alluvial plain. 


\section{ELECTRICAL RESISTIVITY TOMOGRAPHY}

In addition to the SP survey, 13 electrical resistivity tomographies (ERT) were effected in the first $\mathrm{km}$ downstream of the landfill indicated by the triangle ABD in Fig. 2. These tomographies (1) imaged the vadose zone, the aquifer and the marly aquitard, which are units with strongly contrasting resistivity and (2) correlated electrical conductivity (i.e. inverse of electrical resistivity) determined by ERT with the electrical conductivity of the contaminated groundwater measured in boreholes (Table 1). The ABEM multi-electrode Terrameter (SAS-4000) was used with the Wenner configuration and a set of 64 standard stainless electrodes inserted some $10-15 \mathrm{~cm}$ into the ground. The Wenner array was selected because of its good sensitivity to vertical changes in subsurface resistivity (i.e. to horizontal structures), and its very good signal-to-noise ratio. The 13 $2 \mathrm{D}$-electrical resistivity profiles were operated using a uniform electrode spacing of $3 \mathrm{~m}$ and several roll-overs of the set of electrodes.

\section{Interpretation}

\section{SELF-POTENTIAL}

\section{Background in contaminated sites}

The SP signals measured over a contaminated site are associated with two effects: (1) an electrokinetic component associated with the variation of the piezometric head of the aquifer and (2) an electrochemical component associated with the occurrence of oxidoreduction processes. The first contribution is due to the movement of groundwater in the connected pore space in the permeable media. Field experiments showed that this process creates a positive SP anomaly in the flow direction when the reference was taken upstream (Fournier, 1989; Birch, 1993, 1998; Revil et al., 2002; Naudet et al., 2003). The physics of this contribution are well known (Revil et al., 1999).

On the other hand, the underlying physics of SP signals associated with redox phenomena in contaminated sites are not well understood. Various authors (Weigel, 1989; Hämman et al., 1997; Vichabian et al., 1999; Nyquist and Corry, 2002; Nimmer and Osiensky, 2002; Naudet et al., 2003) have observed clear negative SP anomalies associated with contaminant plumes. They suggest that these electrical signals are associated with redox reactions occurring in the contaminant plume. However, to date, there are no useable quantitative interpretation schemes to map the redox potential from a SP map.

\section{Redox environment in contaminant plume}

Before an interpretation scheme of self-potential anomalies is proposed, it is instructive to consider the conditions required for the existence of natural geobattery processes in an organic-rich contaminant plume.

The entry of strongly reduced landfill leachate into the pristine aquifer (often oxidised) modifies the redox environment (Fig. 4). The reduced leachate is rich in both organic matter and $\mathrm{NH}_{4}$, with a great capacity to donate electrons during redox reactions and especially during biodegradation reactions catalysed by bacteria. The oxidation of organic matter is associated with corresponding reduction reactions, including that of oxygen to water, nitrite to elementary nitrogen $\mathrm{N}_{2}$, manganese(III/IV) to manganese(II), iron(III) to iron(II), sulphate to sulphide and $\mathrm{CO}_{2}$ to methane (Christensen et al., 2000, 2001). A series of redox gradients becomes established in the contaminant plume, with an increase in the redox potential value with distance from the landfill. Figure 4 illustrates the development of such redox environments in a contaminant plume associated with landfill leachate.

Microbial activities play a key role in these redox processes because they derive energy from oxidoreduction reactions to maintain life-sustaining processes (Christensen

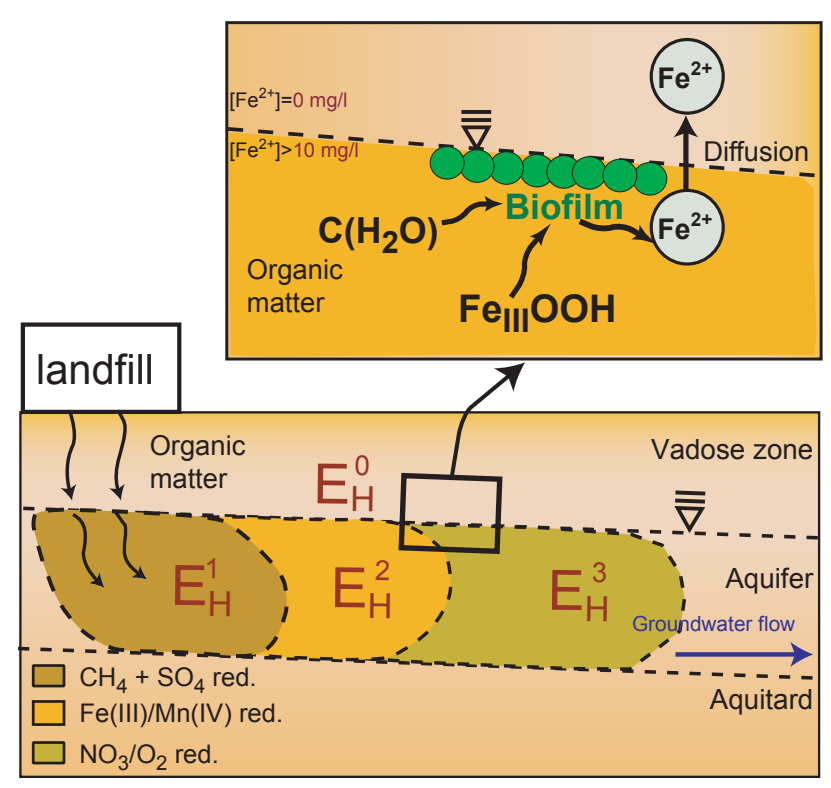

Fig. 4. Illustration of the development of redox zones in a plume associated with landfill leachate with $E_{H 1}<E_{H 2}<E_{H 3}<E_{H O}$. Microbial biodegradation with the oxidation of organic matter by bacteria followed by the reduction of Fe(III) hydroxides is also schematised. The microbial reduction of the Fe(III) hydroxides leads to release of $\mathrm{Fe}^{2+}$ ions, which reach a maximum concentration in the first two cm depth below the water table. As a result of chemical reactions or precipitation, the concentration of dissolved $\mathrm{Fe}^{2+}$ decreases upward. Therefore, dissolved $\mathrm{Fe}^{2+}$ ions diffuse through the upper part of the aquifer. 
et al., 2000, 2001). In organic-rich contaminant plumes, biomass exists either as continuous biofilms covering the surface of the minerals or as microcolonies scattered over the surface of the grains (e.g. Wang and Corapcioglu, 2002 and references therein). The main limiting factors for the growing of bacteria are the nutrients (carbon source) and the availability of oxygen. As long as molecular oxygen is available, it acts as the preferential electron acceptor. It is followed by nitrate, manganese(IV) oxide, iron(III) hydroxides, sulphate, and finally $\mathrm{CO}_{2}$. Consequently, the bacterial activity depends mainly on the depth at which they live. Studies on the bacterial ecology at depths deeper than the vadose zone show that the microbial population decreases considerably as depth increases. Against various types of organic carbon contaminants, bacterial activities are observed to be most effective in biodegradation processes in the rhizosphere, which provides a favourable habitat for bacterial growth with easy accessibility to rich nutrients and moisture (Atlas, 1981).

Recent researches on micro-organisms of marine sediments, both in the laboratory (Bond et al., 2002; Tender et al., 2002) and in the field (Delong, 2002), provide evidence that electricity can be produced from marine sediments thanks to bacterial activity. These experiments lead to the belief that colonies of micro-organisms can transfer electrons between regions of different redox potentials. The electrical current would be generated in the vicinity of the water table, where biofilms are abundant, through a mechanism of charge transfer provided by migration of electrons in biofilm or possibly by diffusion of ions in the water phase. Timm and Möller (2001) have shown that the difference in redox potential contributes as a driving force for self-potential anomalies.

\section{Mapping the redox potential from SP measurements}

Fournier (1989) proposed an equation relating the selfpotential to the variation in hydraulic head, which is its thermodynamic source. A first-order approximation of Fournier's equation has been expressed by Revil et al. (2003):

$$
\varphi-\varphi_{0}=C^{\prime}\left(h-h_{0}\right),
$$

with $\varphi$ (usually expressed in $\mathrm{mV}$ ) representing the selfpotential at the measurement station where the piezometric head is $h$. The parameters $\varphi_{0}$ and $h_{0}$ are the electric potential and the piezometric head variation at the SP base station (where $\varphi_{0}=0 \mathrm{mV}$ by definition) and, $C^{\prime}$ is the electrokinetic coupling coefficient (in $\mathrm{mV}$ per metre of piezometric head variation). To explore a possible correlation between SP signals and redox potential, the redox component must be isolated by removing the electrokinetic component from the SP data. The southern portion of the test site, which is the less contaminated by landfill, was chosen to determine the coupling coefficient $C^{\prime}$ (entering Eqn. (1)). Figure 5 b shows a linear trend $\left(\mathrm{R}^{2}=0.90\right)$ between piezometric head and selfpotential. The equation was $\varphi=-10.60\left(\mathrm{~h}-\mathrm{h}_{0}\right)+56.11$, with the coupling coefficient $C^{\prime}=-10.60 \pm 0.20 \mathrm{mV} \mathrm{m}^{-1}$ and $\varphi_{0}=56.11 \pm 2.10 \mathrm{mV}$. The fact that $\varphi_{0} \neq 0$ is due to a redox effect as explained below. As the standard deviation of the SP measured in the field is around $\pm 20 \mathrm{mV}$ and the $\mathrm{C}^{\prime}$ coefficient is estimated as $\pm 0.2 \mathrm{mV} \mathrm{m}^{-1}$ with a high coefficient of determination $\left(\mathrm{R}^{2}=0.90\right)$, it has been concluded that the SP map is sensitive to less than $2 \mathrm{~m}$ variation in the hydraulic head. The seasonal variation of the water table can affect the SP measurements but the changes in groundwater levels were weak during the seven months of the present study. Therefore, the SP-measurements could not have been affected by these variations and the SP is affected by changes in velocity or flux only because of the influence of the hydraulic pressure variation.

Equation (1) is then used to compute the electrokinetic SP contribution associated with the groundwater flow over the area studied. The electrokinetic contribution is shown in Fig. 5a; its removal from the self-potential map (Fig. 4) results in a residual map $\varphi_{H}$ (Fig. 5c).

To test whether this residual SP signal, $\varphi_{H}$, represents the signature of a natural geobattery associated with the contaminant plume, the residual SP signals were correlated against the redox potential measured in the monitoring wells (Fig. 5d) $\left(\mathrm{R}^{2}=0.85\right)$. Well data were used only where direct SP measurements were available. Well \#15 was rejected because of its location in the clay lens, where the aquifer is thin $(1 \mathrm{~m})$, and where geochemical analyses show unusual variations during the year (Fig. 6).

The relationship between the residual self-potential data $\varphi_{H}$ and measured redox potential $\mathrm{E}_{H}$ shows a linear trend (Fig. 5d):

$$
\varphi_{H}-\varphi_{0}=\mathrm{C}_{H}\left(\mathrm{E}_{H}-\mathrm{E}_{H 0}\right)
$$

where $\varphi_{0}=0, \varphi_{0}$ is the SP measured at the base station including the redox component, $\mathrm{C}_{H}=0.51 \pm 0.09$ the redox coupling coefficient (dimensionless), $\mathrm{E}_{H}$ the redox potential (in $\mathrm{mV}$ ) measured at the SP measurement station, and $\mathrm{E}_{H 0}=56.43 \pm 28.18 \mathrm{mV}$ the redox potential estimated at the SP base station. This linear relationship is then used to convert the residual SP map into a redox potential map. Surprisingly, the value $\mathrm{C}_{H}=0.51$ is in agreement with the theory of Sato and Mooney (1960) related to self-potential in ore deposits. Indeed, in their model all the current lines begin and end at the surface of the ore. Therefore, the 

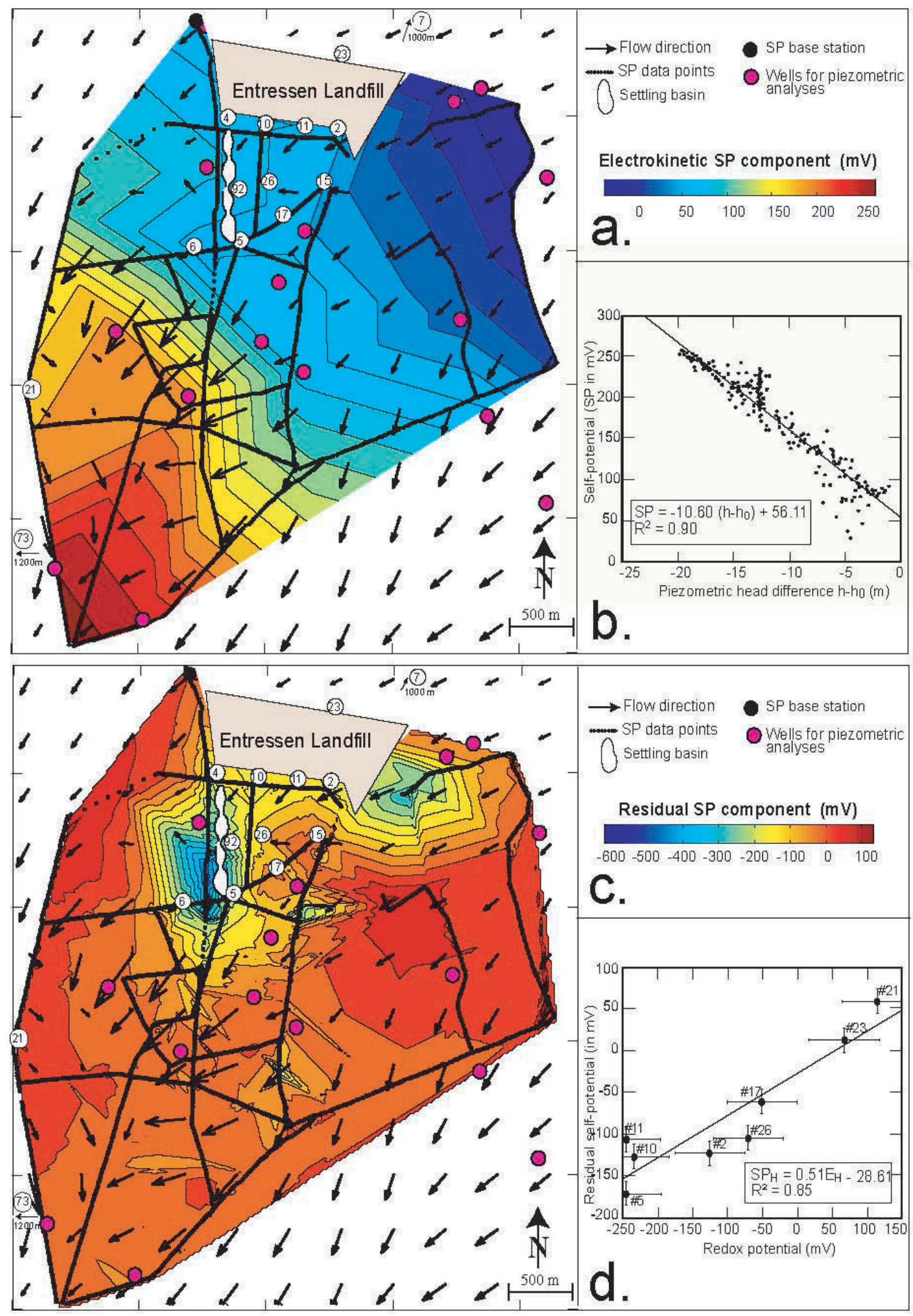

Fig. 5. (a) Map of the electrokinetic component of the self-potential (in $\mathrm{mV}$ ). This map is obtained by linear interpolation of the self-potential calculated from the correlation shown in (5b). (b) Correlation between the piezometric head difference and the self-potential measured in the South portion of the SP test site (Fig. 3). (c) Map of the residual self-potential component (in $\mathrm{mV}$ ) calculated by removing the electrokinetic component from the self-potential measured on the field. (d) Correlation between the redox potential measured on boreholes (numbered circles) with an error of $\pm 50 \mathrm{mV}$, and the residual self-potential component $(5 \mathrm{c})$ estimated with an error of $\pm 20 \mathrm{mV}$. 


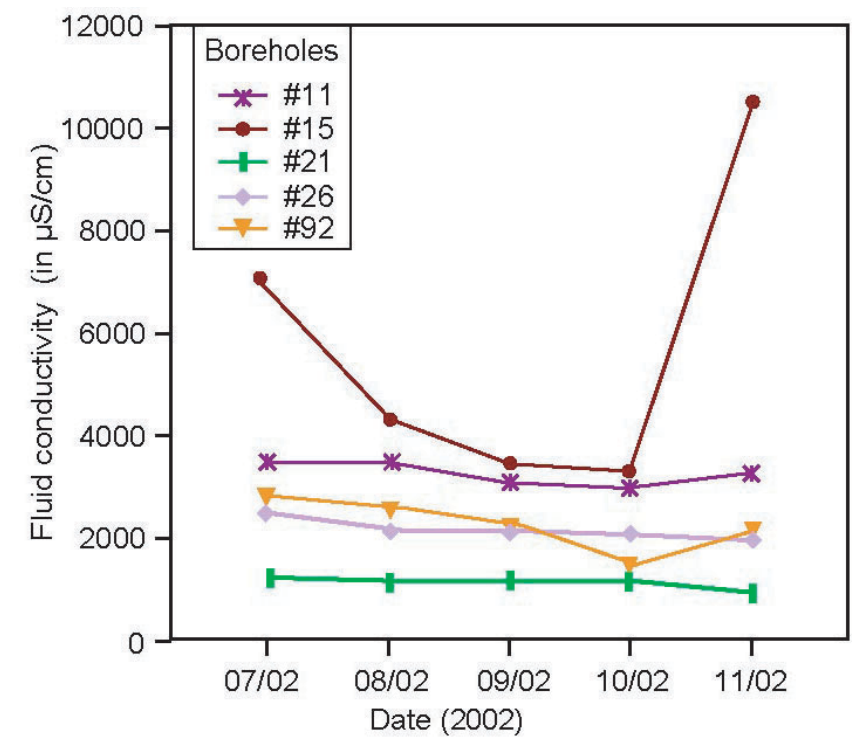

Fig. 6. Variation in electrical conductivity of groundwater measured in boreholes from July to November 2002. The values reported in Table 1 correspond to the mean over these five months.

Measurements of the electrical conductivity performed in the other boreholes have a standard deviation of less than $5 \%$. maximum anomaly expected in a self-potential survey at the ground surface of the Earth would be one-half the maximum potential relative to a point at infinity, i.e. onehalf of the redox potential. The opposite argument, due to Corry (1985) and Nyquist and Corry (2002), is that SPanomalies represent a direct measurement of the redox potential. Clearly, additional field cases are needed before definite conclusions can be reached.

From the redox potential map shown in Fig. 7, the extension of the contaminant plume can be contoured with a somewhat arbitrary boundary, e.g. $\mathrm{E}_{H}=0 \mathrm{mV}$, to delineate the side boundaries of the redox front. The negative redox potential values located in the eastern part of the landfill seem to be associated with a clay zone, which has been identified by borehole data and core analyses and by electrical resistivity tomographies (Fig. 11). The very important negative redox potential value $\mathrm{E}_{H} \approx-1 \mathrm{~V}$ located in the western part of the settling basin, is probably too high because the redox potential is limited in the negative range by the reduction of $\mathrm{H}_{2} \mathrm{O}$ in $\mathrm{H}_{2}(\mathrm{~g})$ and in the positive range by the oxidation of $\mathrm{H}_{2} \mathrm{O}$ in $\mathrm{O}_{2}(\mathrm{~g})$. At $\mathrm{pH} 7$ to 8 , this range is

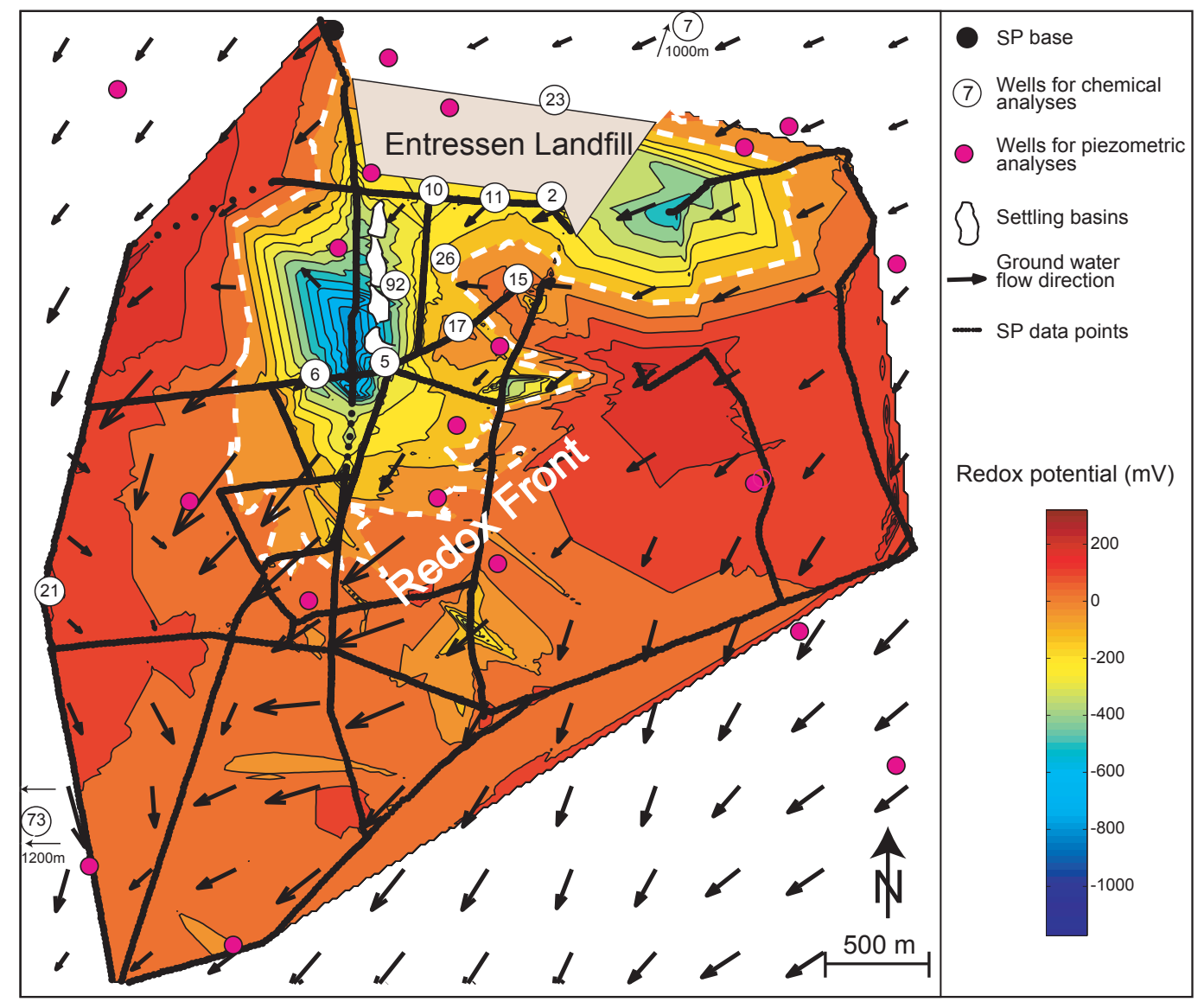

Fig. 7. Redox potential map (in $\mathrm{mV}$ ) calculated with the linear correlation obtained between the redox potential measured in boreholes and the residual self-potential component (Fig. 5d). 
from about $-400 \mathrm{mV}$ to $+800 \mathrm{mV}$. This overestimation is probably associated with the presence of a buried pipe along the western side of the settling basins in a north-south direction. This disturbance can be due to the leak of the alternative electrical current injected along the casing of the pipe to limit its corrosion. Figure 9 shows that the influence of the pipe is very local within a radius of around $50 \mathrm{~m}$ and a negative amplitude in the range of $150-350 \mathrm{mV}$, which leads to an overestimation of the redox potential around $300-700 \mathrm{mV}$.

To conclude this discussion, Fig. 8 is a flowchart which illustrates the different steps in the mapping of redox potential from self-potential.

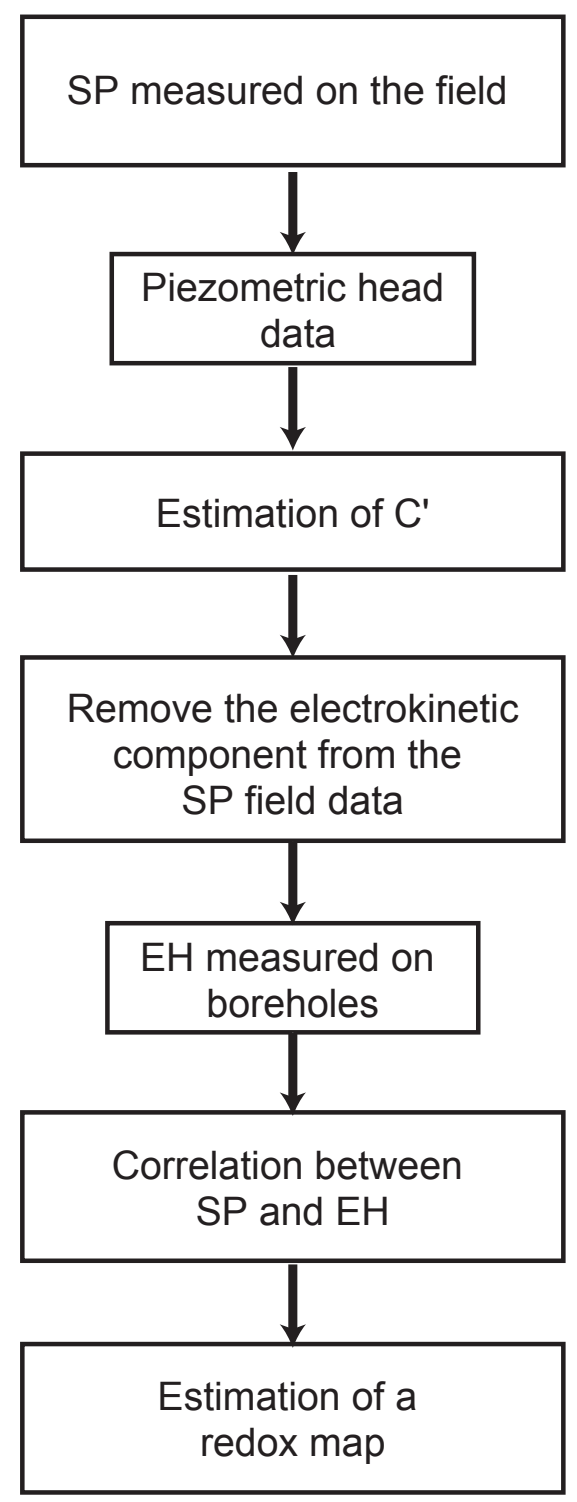

Fig. 8. Flow chart of the different steps to estimate the redox potential from self-potential measurements.

\section{ELECTRICAL RESISTIVITY TOMOGRAPHY}

The electrical resistivity of a soil or rock is dependent on partial water saturation, salinity, and clay content (e.g. Revil et al., 1998). In contaminant plumes, the concentrations of organic contaminants and ions increase the electrical conductivity of the groundwater. Therefore, the overall bulk resistivity of the sediment is expected to be reduced.

\section{Interpretation of the ERT results}

The electrical resistivity profiles were inverted using RES2DINV (Loke and Barker, 1996); the results of the 'robust inversion' method were compared with those of the conventional least-squares method, which minimises the square of the changes in the model resistivity values. This produces a model with a smooth variation in the resistivity values. However, if the subsurface layers have sharp boundaries, the conventional least-square method tends to sharpen these boundaries. Borehole data indicate that the boundary between the marl substratum and the aquifer is sharp, so the robust inversion method was used instead.

Two representative electrical resistivity profiles are shown in Fig. 2. The geological structure is very simple, with three domains with different resistivity ranges. There are: (1) a very shallow resistive zone $(>200 \Omega \mathrm{m})$ corresponding to the vadose zone, (2) a conductive layer corresponding to the unconfined aquifer $(\sim 80-200 \Omega \mathrm{m})$, and (3) a very conductive substratum with very low resistivity values $(\sim 5-$ $80 \Omega \mathrm{m}$ ) composed of marls of Pliocene age. Geological information from available boreholes support this interpretation. The thickness of the aquifer is lowered in the eastern part of the site as a clay-rich lens reaches the ground-surface (profile AB on Fig. 2). This clay lens has also been detected by drilling and coring (well \#15).

\section{Electrical conductivity of the groundwater}

The thirteen 2D-electrical resistivity images (Fig. 10) have been interpolated to obtain a 3D-image of the electrical conductivity (inverse of the resistivity) distribution in the subsurface. An ordinary point Kriging interpolation is used with a grid space of $10 \mathrm{~m}$ and Fig. 11 presents the height slices resulting from the $3 \mathrm{D}$-interpolation. The $3 \mathrm{D}$-image reflects changes in electrical conductivity due to groundwater salinity changes because of the contamination. The relationship between fluid conductivity, measured in monitoring wells, and electrical conductivity from ERT in the saturated zone, can be made for co-located data, assuming some equivalence in scale. The value of the electrical conductivity at the well location is taken as an average of 5 ERT points situated in a circle of $3 \mathrm{~m}$ around the well. In this paper, this relationship has been applied to 

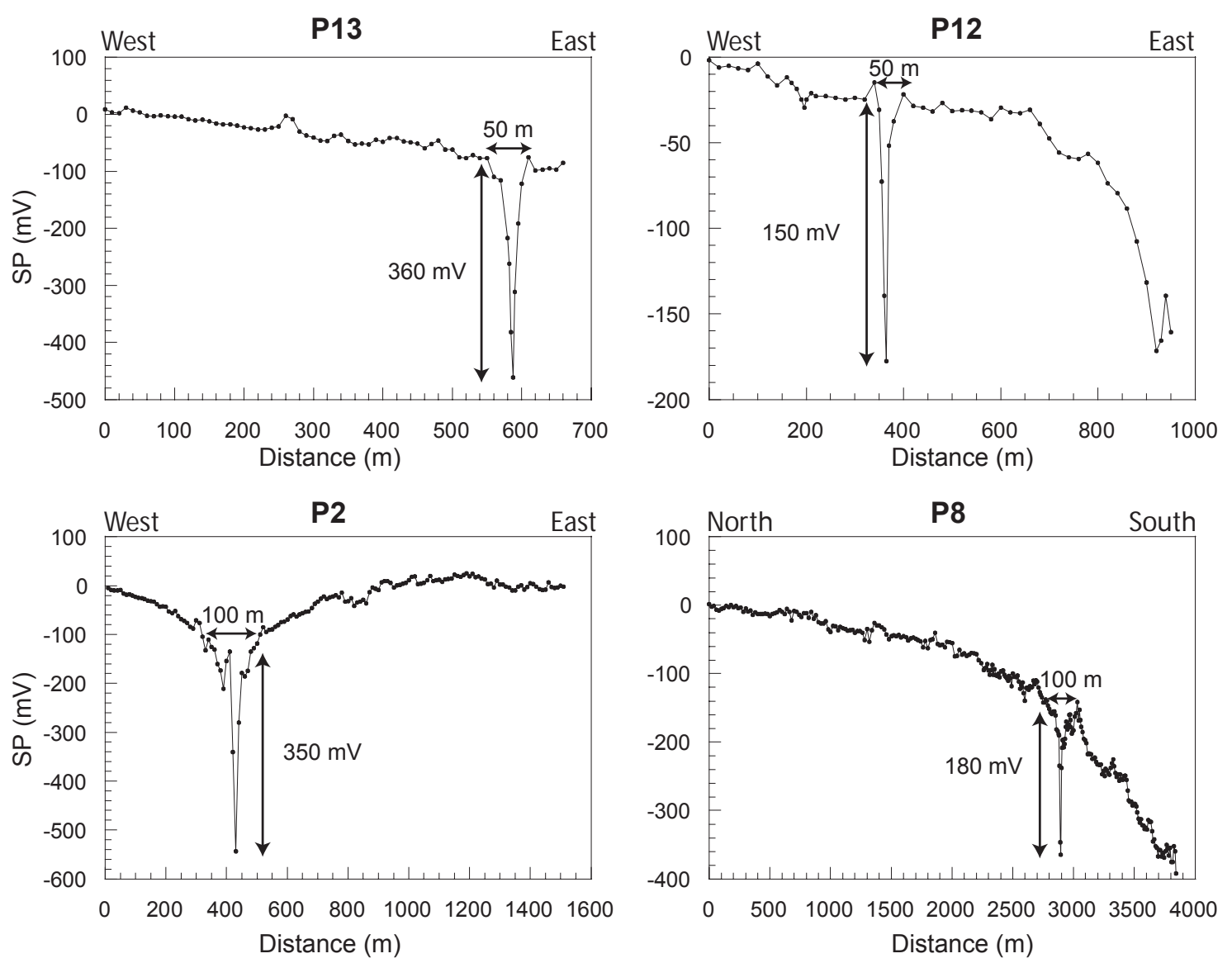

Fig. 9. Influence of the buried pipe over the self-potential measurements on P2, P8, P12 and P13 (located on Fig. 3). The buried pipe lies along the west side of the settling basin in a north-south direction. The pipe disturbs the self-potential measurements locally around 50-100 $\mathrm{m}$ with a negative amplitude of $150-350 \mathrm{mV}$.

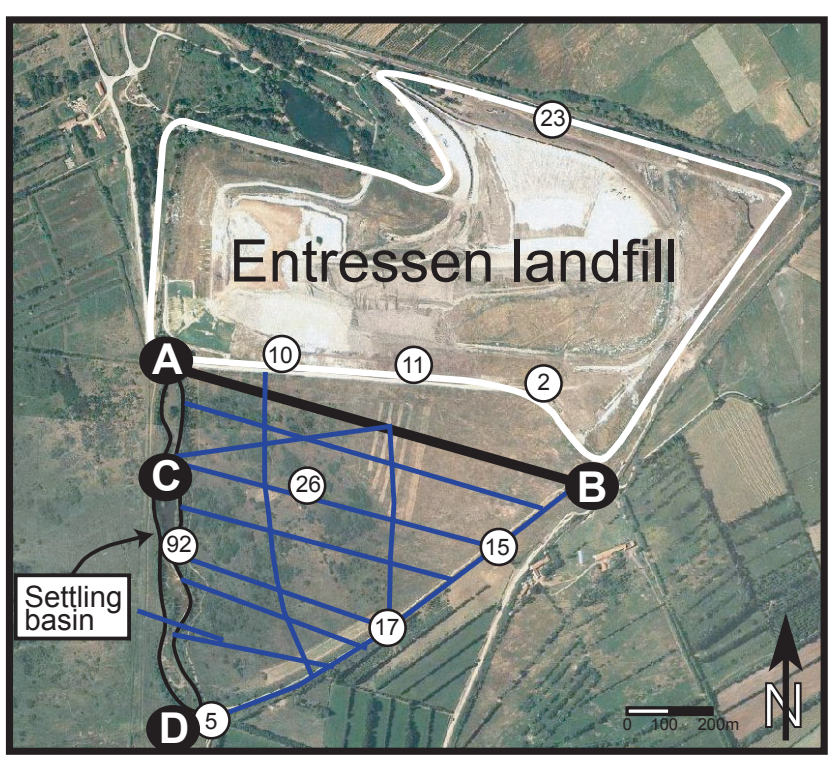

Fig. 10. Location of the thirteen electrical resistivity tomographies (ERT) performed with the Lund Imaging System (ABEM). The Wenner configuration with an electrode spacing of $3 \mathrm{~m}$ was used. the overall zone scanning by the ERT method to transform the electrical conductivity image thus determined to a map of the electrical conductivity of the groundwater (see also Kemna et al., 2002, for an application of ERT to characterise subsurface solute transport).

In isotropic and water-saturated porous media, the bulk electrical conductivity of the rock $\sigma$ (in $\mathrm{S} \mathrm{m}^{-1}$ ) is related to the conductivity of the groundwater, by Waxman and Smits (1968):

$$
\sigma=\frac{\sigma_{f}}{F}+\sigma_{s}
$$

where $\sigma_{f}$ is the electrical conductivity of the fluid (in $\left.\mathrm{S} \mathrm{m}^{-1}\right), \sigma_{s}$ is the surface conductivity occurring in the electrical double layer at the grain-water interface (in $\mathrm{S} \mathrm{m}^{-1}$ ), and $F$ is the formation factor defined by $F=\phi^{-\mathrm{m}}$ (Archie, 1942), with $\phi$ the porosity and $m$ the cementation exponent factor. The cementation factor is usually in the range $1.5-2.5$ with an average value $\sim 2$. More realistic models of electrical conductivity have been developed 


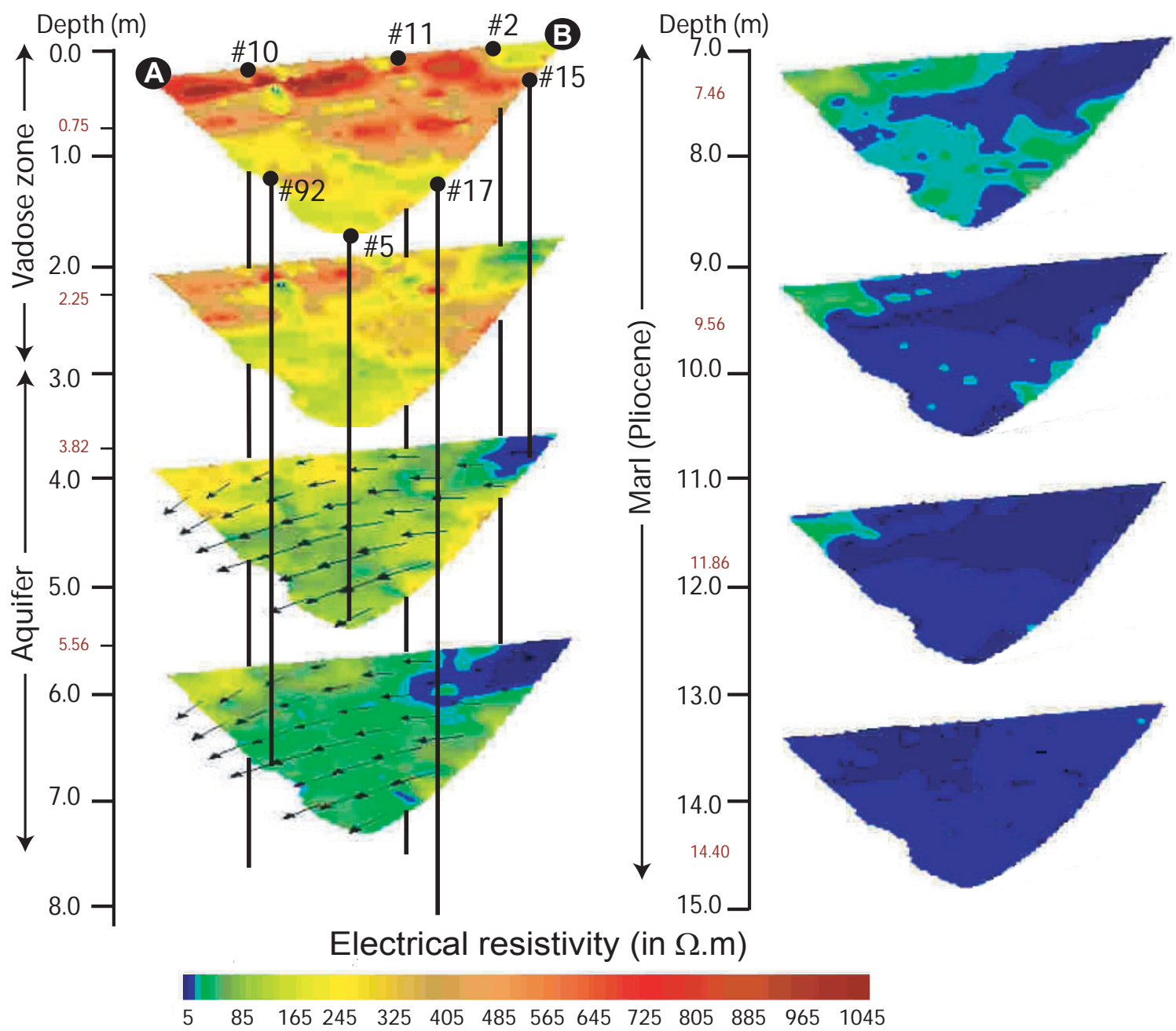

Fig. 11. 3D electrical resistivity tomography (ERT) obtained using the Kriging gridding method with a linear variogram model of the electrical resistivity profiles. The grid spacing for the Kriging is $10 \mathrm{~m}$. Boreholes for chemical and geological measurements are located on the 3D-map.

recently (e.g. Revil et al., 1998) but their use does not change the concluding statements made here.

In clay-bearing rocks, surface conductivity usually predominates over the conductivity of the groundwater because clay particles have a high specific surface area and, thus, a high surface conductivity. In clay-free materials, surface conduction can be neglected and Eqn. (3) reduces to:

$$
\sigma=\sigma_{f} / F
$$

Each electrical conductivity measurement of the groundwater in monitoring wells is associated with an electrical conductivity of the ground (from ERT). This electrical conductivity is chosen at the location of the well, at the depth of the aquifer (slices $z=-3.82 \mathrm{~m}, z=-5.56 \mathrm{~m}$ of Fig. 11). To homogenise the value of this electrical conductivity, the mean of values $3 \mathrm{~m}$ around the well was taken. To obtain the relationship between these two colocated data, the electrical conductivity of the ground was plotted versus the electrical conductivity of the groundwater measured in boreholes (Fig. 13). The electrical conductivity values of the groundwater are mean values of the measurements over the year 2002 (Table 1, Fig. 6). The electrical conductivity measured with ERT is taken at depths $z=-3.82 \mathrm{~m}$ and $z=-5.56 \mathrm{~m}$ where the alluvium is watersaturated according to piezometric levels observed in wells (Fig. 11). Well \#15 was not taken into account because it is above a clay lens, where the thickness of the aquifer is very small $(\sim 1 \mathrm{~m})$. Indeed, the electrical conductivity measurements in this well, during the year 2002, are very unstable with an absolute variation of $0.307 \mathrm{~S} \mathrm{~m}^{-1}$ (Fig. 6).

If the aquifer is free of clays and the formation factor is assumed constant, then the rock conductivity versus the conductivity of the groundwater should be linear, according 

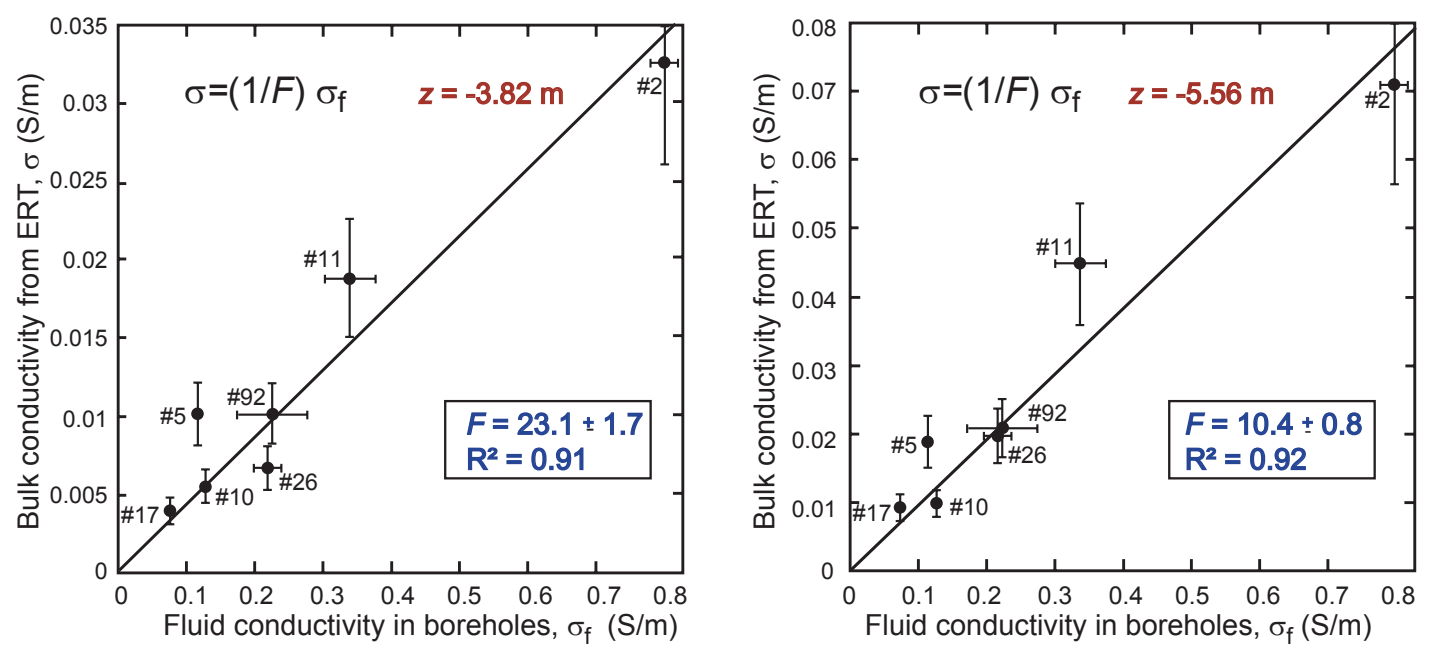

Fig. 12.. Correlation between the fluid conductivity (in $S \mathrm{~m}^{-1}$ ) of the groundwater measured in boreholes and the electrical conductivity (in $S \mathrm{~m}$ 1) obtained from the $3 D$ ERT at the depths $z=-3.82 \mathrm{~m}$ and $z=-5.56 \mathrm{~m}$.
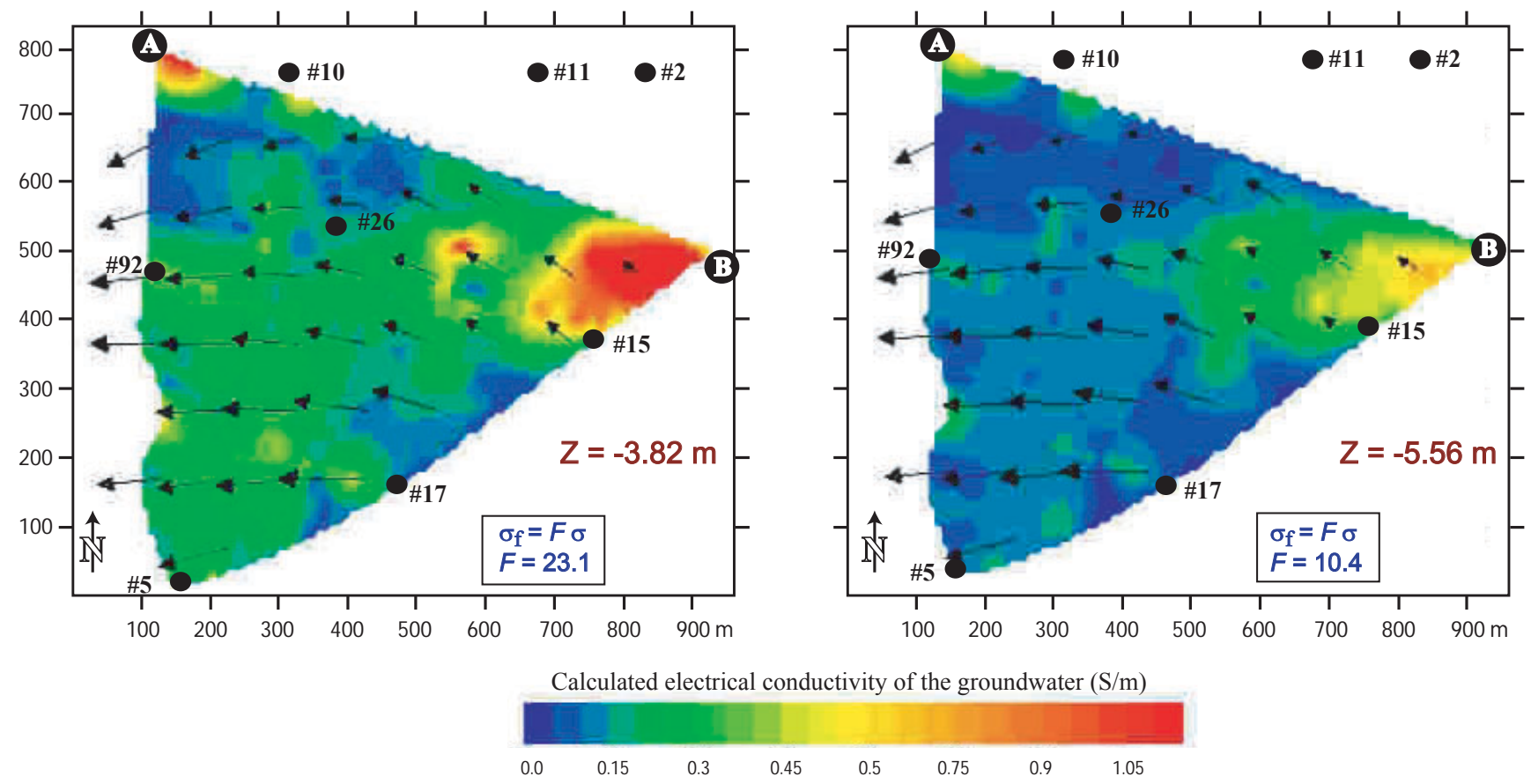

Fig. 13. Maps of the electrical conductivity (in $S \mathrm{~m}^{-1}$ ) of the groundwater calculated from the correlation obtained in Fig. 10. (a) Map at the depth $z=-3.82 \mathrm{~m}$ calculated with a formation factor $F=10.4$. (b) Map at the depth $z=-5.56 \mathrm{~m}$ calculated with a formation factor $F=23.1$. The arrows correspond to the piezometric gradient determined from a triangular interpolation of around forty piezometric head measurements in all the alluvial plain.

to Eqn. (4), with a slope of $1 / F$. Figures $12 \mathrm{a}$ and $12 \mathrm{~b}$ show such a linear correlation at the depths $z=-3.82 \mathrm{~m}$ and $z=-5.56 \mathrm{~m}$, respectively. The line was forced through the origin as suggested by Eqn. (4) for a clay-free rock. There was a good correlation $\left(\mathrm{R}^{2}=0.91\right)$ between the bulk electrical conductivity determined by ERT and the electrical conductivity of the groundwater. The formation factor lies between $23.1 \pm 1.7$ for the upper part and $10.4 \pm 0.8$ for the lower part of the aquifer suggesting an increase in porosity with depth in the aquifer. These two linear relationships were used to convert the electrical conductivity slices into maps of the electrical conductivity of the groundwater. Figures 
$13 \mathrm{a}$ and $\mathrm{b}$ show the resulting maps obtained at depths $z=-3.82 \mathrm{~m}$ and $z=-5.56 \mathrm{~m}$, respectively. These maps indicate the presence of a highly conductive plume, emanating from the eastern part of the landfill, in which waste is presently being deposited. Initially, this plume is relatively narrow $(\sim 200 \mathrm{~m})$ stretching from east to west; then, it spreads more widely downstream, which is characteristic of advective transport of contaminants with mechanical dispersion. Note that the mineralistion of the groundwater (proportional to its electrical conductivity) decreases along the streamlines.

Two additional points merit comment. The first is related to the very high conductivity around point B (Fig. 13a). A clay-free aquifer has been assumed but this site is possibly affected by the clay lens mentioned earlier as extending to the ground surface (Profile AB in Fig. 2). This high conductivity can, therefore, be the result of the surface conductivity of the clay minerals and not of high mineralisation of the groundwater. The second point concerns local heterogeneities in the groundwater flow direction. ERTs show that paleochannels in the western part are responsible for higher hydraulic transmissivities along their direction. The arrows shown in Fig. 13 are piezometric head gradients interpolated from piezometric data and provide only a crude estimation of groundwater flow direction. Nevertheless, they indicate a change in the direction of the groundwater flow due to paleochannels and a clay lens in the more eastern portion of the landfill. The fact that the contaminant plume seems more focused in the S-W direction close to the settling basins could be because of local preferential flow paths associated with these paleochannels. ERT with a higher density of points and a closer electrode spacing could confirm this point.

\section{Conclusion}

This study shows an application of the self-potential method and electric resistivity tomography to a contaminated site. These geophysical methods provide useful spatial information on the quality of the groundwater. Reasonable correlations are obtained between geoelectrical and geochemical parameters. The residual self-potential map calculated by removing the electrokinetic component to the measured self-potential data shows a rather good linear correlation $\left(\mathrm{R}^{2}=0.85\right)$ with the measurements of the redox potential in boreholes. This indicates that the gradient of the redox potential is the driving force for the self-potential signals in a natural geobattery process in which biofilms could play an important role. A redox potential map can be determined and used to delineate the redox front of the contaminant plume. Electrical conductivity values, obtained from the 3D-electrical resistivity tomography, are also well correlated $\left(\mathrm{R}^{2}=0.91\right)$ with the electrical conductivity of the fluid measured in boreholes. This indicates that the formation factor is nearly homogeneous in the aquifer at the scale of the electrical resistivity tomography $(3 \mathrm{~m}$ in electrode spacing). With this relationship, a map of the fluid conductivity downstream, showing the position of the contaminant plume, was obtained. It appears that the selfpotential method can be used as a cheap monitoring method to provide pertinent information about the evolution of a contaminant plume and possible landfill leakage. To understand the underlying physics of self-potential anomalies in the context of contaminant plumes, it would be necessary to undertake sand-box experiments in controlled conditions using the self-potential method to monitor variations in redox conditions.

\section{Acknowledgements}

The city of Marseille is thanked for access to the site and for the chemical analyses. Financial support by ADEME through a PhD grant to V. Naudet, CNRS, and by the Ministère de la Recherche et de l'Education Nationale (ACIJeune \#0693 to A. Revil, and by ACI Eau et Environnement to D. Gibert and A. Revil) are acknowledged. B. Hamelin is thanked for his support, D. Hermitte and M. Pessel for their help in the field, G. Bourrié and F. Trolard for fruitful discussions and Jan Seibert for his encouragement through the YSOPP (Young Scientist Outstanding Poster Paper) in Hydrological Sciences competition at the EGS-AGU-EUG Assembly, in Nice, in April 2003.

\section{References}

Archie, G.E., 1942. The electrical resistivity $\log$ as an aid in determining some reservoir characteristics. Amer. Inst. Min. Metallurg. Petr. Eng., 146, 54-62.

Aristodemou, E. and Thomas-Betts, A., 2000. DC resistivity and induced polarisation investigations at a waste disposal site and its environments. J. Appl. Geophys., 44, 275-302.

Atlas, R.M., 1981. Microbial degradation of petroleum hydrocarbons: an environmental perspective. Microbiol. Rev., 45, 180-209.

Binley, A.M., Cassiani, G., Middleton, R. and Winship, P., 2002. Vadoze zone flow model parameterisation using cross-borehole radar and resistivity imaging. J. Hydrol., 267, 147-159.

Birch, F.S., 1998. Imaging the water table by filtering self-potential profiles. Ground Water, 36, 779-782.

Bond, D.R., Holmes, D.E., Tender, L.M. and Lovley, D.R., 2002. Electrode-reducing micro-organisms that harvest energy from marine sediments. Science, 295, 483-485.

Buselli, G. and Lu, K., 2001. Groundwater contamination monitoring with multichannel electrical and electromagnetic methods. J. Appl. Geophys., 48, 11-23. 
Christensen, T.H., Bjerg, P.L., Banwart, S.A., Jakobsen, R., Heron, G. and Albrechtsen, H.-J., 2000. Characterization of redox conditions in groundwater contaminant plumes. J. Contam. Hydrol., 45, 165-241.

Christensen, T.H., Kjeldsen, P., Bjerg, P.L, Jensen, D.L., Christensen, J.B., Baun, A., Albrechtsen, H.-J. and Heron G., 2001. Biogeochemistry of landfill leachate plumes. Appl. Geochem., 16, 659-718.

Corry, E., 1985. Spontaneous polarization associated with porphyry sulfide mineralization. Geophysics, 50, 1020-1034.

Corwin, R.F., 1990. The self-potential method for environmental and engineering applications. Geotech. Environ. Geophys., 1, Review and Tutorial, S.H.Ward (Ed.), Society of Exploration Geophysics, Tulsa, OK, USA.127-145.

Delong, E., 2002. L'électricité bactérienne, plus qu'une curiosité. La Recherche, 358, 17.

Doussan, C., Jouniaux, L. and Thony, J.-L., 2002. Variations of self-potential and unsaturated water flow with time in sandy loam and clay loam soils. J. Hydrol., 267, 173-185.

Fournier, C., 1989. Spontaneous Potentials and resistivity surveys applied to hydrogeology in a volcanic area : case history of the Chaîne des Puys (Puy-de-Dôme, France). Geophys. Prospect., 37, 647-668.

Hämmann, M., Maurer, H.R., Green, A.G. and Horstmeyer, H., 1997. Self-potential image reconstruction: capabilities and limitations. J. Environ. Eng. Geophys., 2, 21-35.

Kemna, A., Vanderborgh, J., Kulessa, B. and Vereecken, H., 2002. Imaging and characterisation of subsurface solute transport using electrical resistivity tomography (ERT) and equivalent transport models. J. Hydrol., 267, 125-146.

Loke, M.H. and Barker, R.D., 1996. Rapid least-squares inversion of apparent resistivity pseudosections by a quasi-Newton method. Geophys. Prospect., 44, 131-152.

Minsley, B.L., Sogade, J., Briggs, V., Lambert, M., Reppert, P., Coles, D., Rossabi, J., Riha, B., Shi, W. and Morgan, F.D., 2003. Three dimensional inversion of a self-potential dataset for contaminant detection and mapping at the Savannah River site, South Carolina. AGU Fall Meeting December 2003 in San Francisco, Poster H31B-0462.

Naudet, V., Revil, A., Bottero, J.-Y. and Bégassat, P., 2003. Relationship between self-potential (SP) signals and redox conditions in contaminated groundwater. Geophys. Res. Lett., 30, 2091, doi:10.1029/2003 GL018096.

Nimmer, R.E. and Osiensky, J.L., 2002. Direct current and selfpotential monitoring of an evolving plume in partially saturated fractured rock. J. Hydrol., 267, 258-272.

Nyquist, J.E. and Corry, C.E., 2002. Self-potential: the ugly duckling of environmental geophysics. The Leading Edge, 21, 446-451.

Petiau, G., 2000. Second generation of lead-lead chloride electrodes for geophysical applications. Pure Appl. Geophys., 157, 357-382.

Revil, A., Cathles, III L.M., Losh, S. and Nunn, J.A., 1998. Electrical conductivity in shaly sands with geophysical applications. J. Geophys. Res., 103, 23,925-23,936.
Revil, A., Schwaeger, H., Cathles, L.M. and Manhardt, P.D., 1999. Streaming potential in porous media. 2. Theory and application to geothermal systems. J. Geophys. Res., 104, 20,023-20,048.

Revil, A., Hermitte, D., Voltz, M., Moussa, R., Lacas, J.-G., Bourrié, G. and Trolard, F., 2002. Self-potential signals associated with variations of the hydraulic head during an infiltration experiment. Geophys. Res. Lett., 29, doi:10.1029/ 2001GL014294.

Revil, A., Naudet, V., Nouzaret, J. and Pessel, M., 2003. Principles of electrography applied to self-potential electrokinetic sources and hydrogeological applications. Water Resour. Res., 39, 1114, doi:10.109/2001WR000916.

Sato, M. and Mooney, H.M., 1960. The electrochemical mechanism of sulfide self-potentials. Geophysics, 25, 226-249.

Schulte-Ebbert, U. and Hofmann, T., 2000. Measurement of Redox Potentials at the Test Site Insel Hengsen. In: Redox. Fundamentals, Processes, and Applications J. Schüring, H.D. Schulz, W.R. Fischer, J. Böttcher and W.H.M. Duijnisveld, (Eds.), Spinger, Berlin, Germany. 251pp.

Tender, L.M., Reimers, C.E., Stecher, H.A., Holmes, D.E., Bond, D.R., Lowy, D.A., Pilobello, K., Fertig, S.J. and Lovley, D., August 2002. Harnessing microbially generated power on the seafloor. Nature Biotechnology, 20, 821-825.

Timm, F. and Möller, P., 2001. The relation between electric and redox potential: an evidence from laboratory to field experiments. J. Geochem. Explor., 72, 115-127.

Titov, K., Ilyin, Y., Konosavski, P. and Levitski, A., 2002. Electrokinetic spontaneous polarization in porous media: petrophysics and numerical modelling. J. Hydrol., 267, 207216.

Vayenas, A.C., 2002. Visualization experiments of biodegradation in porous media and circulation of the biodegradation rate. $A d v$. Water Resour., 25, 203-219.

Vichabian, Y., Reppert, P. and Morgan, F.D., 1999. Self potential mapping of contaminants. Proc. Symp. Application of Geophysics to Engineering and Environmental Problems, March 14-18, SAGEEP.

Vilomet, J.-D., Angeletti, B., Moustier, S., Ambrosi, J.-P., Wiesner, M., Bottero, J.-Y. and Chatelet-Snidaro, L., 2001. Application of strontium isotopes for tracing landfill leachate plumes in groundwater. Environ. Sci. Technol., 35, 4675-4679.

Wang, S. and Corapcioglu, M.Y., 2002. Simulation of bioaugmentation involving exogenous bacteria injection. Water Resour. Res., 38, 1293, doi:10.1029/2001WR000344.

Waxman, M.H. and Smits, L.J.M., 1968. Electrical conduction in oil-bearing shaly sands. J. Soc. Petr. Eng., 8, 107-122.

Weigel, M., 1989. Self-potential surveys on waste dumps. Theory and Practice in Detection of Subsurface Flow Phenomena. Lecture Notes in Earth Sciences, 27, G.-P. Merkler et al. (Eds.), Detection of Subsurface Flow Phenomena, Springer, Heidelberg, Germany. 109-120.

Yaramanci, U., 2000. Geoelectric exploration and monitoring in rock salt for the safety assessment of underground waste disposal sites. J. Appl. Geophys., 44, 181-196. 